\title{
Frequency of Class I Anti-HLA Alloantibodies in Patients Infected by HIV-1
}

\author{
Elza Regina Manzolli Leite ${ }^{1 *}$, Oswaldo Luiz Luz Lima², Fábio Renato Manzolli Leite ${ }^{3}$ and \\ Paulo Inácio da Costa ${ }^{1}$ \\ ${ }^{1}$ Faculdade de Ciências Farmacêuticas de Araraquara; Universidade Estadual Paulista; 14801-902; Araraquara - \\ SP - Brasil. ${ }^{2}$ Serviço Especial de Saúde - Adolpho Lutz; Araraquara - SP - Brasil. ${ }^{3}$ Faculdade de Odontologia; \\ Universidade Federal de Pelotas; Pelotas - RS - Brasil
}

\begin{abstract}
The aim of this study was to evaluate the presence of class I anti-HLA alloantibodies in patients infected by HIV-I and relate it with the different clinical courses of the disease. Blood samples were collected in EDTA tubes from 145 individuals. HIV-1 infection was confirmed by ELISA test. The presence of class I anti-HLA alloantibodies and HLA allele's were determined. Clinical evolution was set as fast ( $<1$ year between diagnostic and death), moderate (1-3 years) or slow (>3 years). Class I anti-HLA alloantibodies presence was lower in healthy individuals than in those infected by HIV-1 (4.2\% against 32.4\%). However, an equal distribution of these alloantibodies was found among the individuals infected, independent on the clinical evolution. Thus, class I anti-HLA alloantibodies was not a determinant factor for patient worsening.
\end{abstract}

Key words: AIDS, HIV, HLA antigens, alloantibodies

\section{INTRODUCTION}

AIDS is caused by the Human Immunodeficiency Virus type 1 (HIV-1) infection, a retrovirus belonging to the Retroviridae family, Lentivirinae subfamily. The lentiviruses are able to cause latent cell infection or cytopathic effects in short term, including lethal and slowly progressive diseases, i.e., weakness, loss of weight and central nervous system degeneration (Greene, 1991; Abbas et al., 2000). Clinical consequences of HIV infection are due to its ability to disarm the host immune system. This process occurs because the primary target of the virus is the helper lymphocyte subgroup. AIDS main characteristic is the CD4+ T lymphocytes (CD4+ LT) selective depletion, cell that plays a central role for most immune responses because of its interaction with the major histocompatibility complex (MHC) (Rhame, 1989; Feinberg, 1996). HIV infection leads to CD4+ LT lyses or functional inactivation, in both cases, the reduction in helper lymphocytes number or activity results in damage to cellular and humoral immune responses.

The primary infection by HIV-1 can be asymptomatic, but frequently, patients present an acute viral syndrome with multiform manifestation, the most common are fever, lymphadenopathy, pharyngite and cutaneous eruption. AIDS is characterized by extreme heterogeneity in its clinical course, probably due to the genetic variability of the virus; the chemokines receptors (Havlir, 1998), or because of the genetic differences from host to host, i.e.,

\footnotetext{
*Author for correspondence: elza.leite@gmail.com
} 
human leukocyte antigen (HLA) genotype associated to the immune response (Fabio et al., 1992; Carrington et al., 1999). After the initial phase, the extracellular viruses disappear, but the latent infection present on CD4+ lymphocytes, macrophages and microglia cells on central nervous system continues (Roitt et al., 2001).

The progressive depletion of $\mathrm{CD} 4+\mathrm{T}$ helper lymphocyte population starts just after the primary infection. Normal levels of CD4 cells $/ \mathrm{mm}^{3}$ can fall from \pm 1000 to less than 50 cells $/ \mathrm{mm}^{3}$ and in extreme cases, to less than 10 cells $/ \mathrm{mm}^{3}$ (Pedersen et al., 1989; Graziosi et al., 1993; Tindall et al., 1993). The risk of complications and opportunist infections increases drastically when CD4 level is lower than 100 cells $/ \mathrm{mm}^{3}$ (Walker, 1997; Cavert, 1998).

Beretta et al. (1996), after studying the serum positive patients for HIV with serum negative partners, described three kinds of distinct reactivity, which can occur concomitantly in infected patients: anti-CD4 and class I anti-HLA alloantibodies synthesis and the existence of specific $T$ helper cells against peptides of the envelop. In parallel to AIDS progression, a disturbance in the mechanism, which recognizes what is self or not-self could occur, suggesting an important role inn the self-immune pathogenic mechanism, just like in graft versus host diseases (GVHD) (Habeshaw et al., 1992; Silvestris et al., 1995). This could, in part, explain the diversity on clinical evolution of HIV infected patients.

According to Habeshaw et al. (1992) and Silvestris et al. (1995), the similarity between the structural parts of HIV-1 and MHC class I is the most compromising immune response for the patient. Antibodies anti-HIV can recognize common sequences from the alpha-helix of the heavy chain of class I HLA molecules and the C5 region of gp 120 on a cross-reaction. This would be one of the many examples of molecular mimetization observed in HIV assays. Some authors have suggested that the diversity and distribution of the allelic frequency of genes from MHC class I and II could be related to the morbidity of some diseases, i.e., AIDS (Mann et al., 1990; Just, 1995; Kaslow et al., 1996). Carrington et al. (1999) suggested that among all the HIV-1 carriers, the heterozygotes for HLA antigens displayed an advantage on homozygotes. The former should present a slower clinical course than the latter in terms of disease progression. Heterozygotes present higher diversity of aminoacids at MHC domains and can develop more effective immunogenic responses. In some populations, the increase on particular allele's frequency in patients affected by some diseases has been observed (Solheim et al., 1982; Tiwari and Terasaki, 1985; Nepon and Erlich, 1991). The presence or absence of MHC molecules seems to modify the immune response, including the level of antibody production and the resistance or susceptibility to infectious, self-immune and allergic diseases (Roitt et al., 2001).

Currently, not much is known about the presence of anti-HLA in patients infected by HIV. Some studies have suggested the presence of these antibodies as responsible for the self-immunity presented by some patients (Silvestirs et al., 1995; Beretta et al., 1996). Klaassen et al. (1990) analyzed the relationship between the presence of self-antibodies against neutrophils and platelets of patients infected by HIV, symptomatic or not. They suggested that these antibodies when present, could act precociously increasing its title on the symptomatic phase and its prevalence could be correlated with the disease progression.

The aim of this study was to evaluate the presence of class I anti-HLA alloantibodies on blood plasma in HIV-1 infected patients under different clinical, immunological and viral courses.

\section{MATERIALS AND METHODS}

One hundred and forty-five adults aging more than 18 years old, both sexes, infected by HIV-1 were studied by a physician from the Health Special Service of Araraquara (SESA) during four years. Blood samples were collected in EDTA Vacutainer tubes and HIV-1 infection was confirmed by ELISA. CD4+ and CD8+ LT subtyping was realized by flow cytometry with simultaneous labeling by direct and doublecoloration (FacsCount, BD Immunocytometry Systems, California, USA). Three categories were established according to the number of CD4+ $\mathrm{LT} / \mathrm{mm}^{3}$ : less than 200 , between 200 and 350 , higher than 350. HIV-1 viral nucleic acid was isolated from fresh plasma by electrochemiluminescence with limit of detection between 80 to $1,000,000$ viral copies $/ \mathrm{mL}$ of plasma (EQL Nuclisens System, Organon Teknika, Holland, Netherlands). The patients were divided into three categories according to the 
number of viral copies/mL: less than 10,000 , between 10,000 and 30,000 and more than 30,000. The QuikScreen ${ }^{\circledR}$ kit (GTI, Brookfield, WI) was used to determine the solid phase HLA antibodies, IgG class, against class I HLA antigens. Results were obtained by multiplying the mean of the three negative control readings by two: $[(x+y+z): 3]$ x $2=$ reference value. All the readings equal or higher than the reference value were considered positive for anti-HLA antibody presence. Inconclusive results were the samples with values up to $10 \%$ of the reference value as suggested by the manufacturer. The clinical evolution considered the time between the clinical diagnosis (symptoms appearance) and death. Clinical course was set as slow (S), when this period of time was under one year, moderate (M) between one and three years and quick $(\mathrm{Q})$ period higher than three years. These categories have been employed at the public health service in order to determine the prescription or not of antiretroviral. When plasma viral charge was under
10,000 viral copies/mL of plasma and/or CD4+ LT were above 350 cells $/ \mathrm{mm}^{3}$, antiretroviral treatment was not recommended. Between 10,000 and 30,000 copies $/ \mathrm{mL}$ and/or CD4+ LT between 200 and 350 cells $/ \mathrm{mm}^{3}$, treatment depended on other factors, for example patient symptoms of the disease. For viral charge above 30,000 copies $/ \mathrm{mL}$ and/or CD4+ LT lower than 200 cells $/ \mathrm{mm}^{3}$, patient received specific medication for HIV. Data were statistically evaluated by means of chi-square test $(\mathrm{p}<0.05)$.

\section{RESULTS}

The frequency and percentage of class I anti-HLA alloantibodies according to clinical evolution, number of CD4+ LT and viral charge are shown in Tables 1, 2 and 3, respectively. However, no differences were found employing the chi-square test.

Table 1 - Anti-HLA antibodies frequency and percentage in patients infected by HIV-1 according to clinical evolution

\begin{tabular}{ccccc}
\hline Evolution & Negative & Positive & Inconclusive & Total \\
\hline Slow & $42(58.3 \%)$ & $23(31.9 \%)$ & $7(9.7 \%)$ & $72(49.6 \%)$ \\
Moderate & $24(70.5 \%)$ & $10(29.4 \%)$ & - & $34(23.4 \%)$ \\
Quick & $21(53.8 \%)$ & $14(35.9 \%)$ & $04(10.3 \%)$ & $39(27.0 \%)$ \\
Total & $87(60.0 \%)$ & $47(32.4 \%)$ & $11(7.6 \%)$ & $145(100.0 \%)$ \\
\hline
\end{tabular}

$\mathrm{p}=0.3731$

Table 2 - Anti-HLA antibodies presence and frequency according to CD4+ LT value

\begin{tabular}{ccccc}
\hline CD4+ LT $\left(\mathbf{m m}^{\mathbf{3}}\right)$ & Inconclusive & Negative & Positive & Total \\
\hline$>350$ & $5(7.3 \%)$ & $42(61.8 \%)$ & $21(30.9 \%)$ & $68(46.9 \%)$ \\
$200-350$ & $4(11.4 \%)$ & $19(54.3 \%)$ & $12(34.3 \%)$ & $35(24.1 \%)$ \\
$<200$ & $2(4.8 \%)$ & $26(61.9 \%)$ & $14(33.3 \%)$ & $42(29.0 \%)$ \\
Total & $11(7.8 \%)$ & $87(59.3 \%)$ & $47(32.8 \%)$ & $145(100.0 \%)$ \\
\hline $\mathrm{p}=0.8307$ & & &
\end{tabular}

Table 3 - Anti-HLA antibodies presence and frequency according to viral category

\begin{tabular}{ccccc}
\hline Viral charge & Inconclusive & Negative & Positive & Total \\
\hline$<10.000$ & $9(12,5 \%)$ & $42(8,3 \%)$ & $21(29,2 \%)$ & $72(49,7 \%)$ \\
$10.000-30.000$ & - & $19(5,5 \%)$ & $10(34,5 \%)$ & $29(20 \%)$ \\
$>30.000$ & $2(4,5 \%)$ & $26(59,1 \%)$ & $16(36,4 \%)$ & $44(30,3 \%)$ \\
Total & $11(7,6 \%)$ & $87(60.0 \%)$ & $47(32,4 \%)$ & $145(100.0 \%)$ \\
\hline
\end{tabular}




\section{DISCUSSION}

HLA genotype has been implicated as one of the responsible for AIDS clinical evolution. Some authors have suggested that anti-HLA antibodies in patients infected by HIV-1 was one of the responsible for clinical worsening of patients and also, could possibly cause self-immune diseases (Silvestris et al., 1995; Beretta et al., 1996). This study focused the frequency of alloantibodies in patients infected by HIV-1. Evaluating the 145 patients recruited in this analysis, the percentage of HIV-1 infected patients with antibodies antiHLA were $32.4 \%$. Beretta et al. (1996) after analyze 90 healthy patients, found these antibodies only in $4.2 \%$. Considering only the patients with worse clinical evolution, this percentage was sustained $(31.9 \%)$ and the same was with those with better evolution (35.9\%).

Because a clinical evaluation can be subjective, comparisons between the frequencies of anti-HLA and the immunologic (CD4+ LT count) and between the frequencies of anti-HLA and viral categories (count of viral copies/mL of plasma) were carried out. Even in this analysis, the percentage of patients in each clinical category evaluated (better and worse) was practically nonaltered.

It is important to state that the results termed as inconclusive were close to the positive cut-off line, which meant that the number of positive patients for alloantibodies could be even higher. New investigations with more patients must be done to evaluate the influence of these alleles and alloantibodies at HIV infection to establish the reactivity of the alloantibodies (anti-HLA or antiHIV) and also to verify the relationship between these alloantibodies with the decline of the immune response in HIV carriers.

Present results suggested that although alloantibodies IgG class I anti-HLA have appeared with higher frequency among the patients infected by HIV-1 virus, they were uniformly present in all the different phases of the disease.

\section{List of abbreviations}

HIV - Human immunodeficiency virus

CD4+ LT - CD4+ T lymphocyte

MHC - Major histocompatibility complex

HLA - Human leukocyte antigen

GVHD - Graft versus host disease

\section{ACKNOWLEDGEMENTS}

The authors thank all the employees from SESA and $\mathrm{CACH}$ (Coordenadoria de Análises Clínicas e Hemoterapia - UNESP) who helped with data and tests.

\section{RESUMO}

O objetivo deste estudo foi avaliar a presença de aloanticorpos anti-HLA classe I em pacientes infectados pelo HIV-1 e relacioná-la aos diferentes cursos clínicos da doença. Amostras de sangue de 145 indivíduos HIV positivo foram coletadas em tubos com EDTA. A infecção pelo HIV-1 foi confirmada por teste ELISA e a presença de aloanticorpos anti-HLA classe I determinada em seguida. A evolução clínica foi definida como rápida $(<1$ ano entre diagnóstico e morte), moderada (1-3 anos) ou lenta ( $>3$ anos). A presença de aloanticorpos anti-HLA classe I foi menor em indivíduos saudáveis em relação aos infectados pelo HIV-1 (4,2\% contra $32,4 \%)$. Porém, a distribuição destes aloanticorpos entre os indivíduos infectados foi igual, independente da evolução clínica. Deste modo, a presença de aloanticorpos anti-HLA classe I não é um fator determinante na piora clínica do paciente.

\section{REFERENCES}

Abbas, A. K.; Lichtman A. H.; Pober, J. S. (2000), Cellular and Molecular Immunology. Philadelphia: WB Saunders.

Beretta, A.; Furci, L.; Burastero S., Cosma A.; Dinelli M. E.; Lopalco L.; De Santis, C.; Tambussi G.; Carrow, E.; Sabbatani, S.; Clerici, M.; Lazzarin, A.; Siccardi, A. G. (1996), HIV-1-specific immunity in persistently seronegative individuals at high rish for HIV infection. Immunol. Lett., 51, 39-43.

Carrington, M.; Nelson, G. W.; Martin, M. P.; Kissner, T.; Vlahov, D.; Goedert, J.; Kaslow, R.; Buchbinder, S.; Hoots, K.; O'brien, S. J. (1999), HLA and HIV-1: Heterozygote Advantage and B*35-Cw*04 Disadvantage. Science, 283, 1748-1751.

Cavert, W. (1998), In vivo detection and quantitation of HIV in blood and tissues. AIDS, 12, 27-34.

Fabio, G.; Scorza, S. R.; Lazzarin, A.; Marchini, M.; Zarantonello, M.; D’Arminio, A.; Marchisio, P.; Plebani, A.; Luzzati, R.; Costigliola, P. (1992), HLA associated susceptibility to HIV-1 infection. Clin Exp Immunol, 1, 20-23. 
Feinberg, M. B. (1996), Chaning the natural history of HIV disease. Lancet, 348, 239-246.

Graziosi, C.; Pantaleo, G.; Butin, L.; Demasrest, J. F.; Saag, M. S.; Shaw, G. M.; Fauci, A. S. (1993), Kinetics of human immunodeficiency virus type 1 (HIV-1) DNA and RNA synthesis during primary HIV-1 infection. Proc. Natl. Acad. USA, 90, 64056409.

Greene, W. C. (1991), The molecular biology of human immunodeficiency virus type 1 infection. N. Engl. J. Med., 324, 308-317.

Habeshaw, J.; Hounsell, E.; Dagleish, A. (1992), Does the HIV envelope induce a chronic graft-versus-hostlike disease? Immunol. Today., 13, 207-210.

Havlir, D. V. (1998), New antiretroviral and new combinations. AIDS, 12, 165-174.

Just, J. J. (1995), Genetic predisposition to HIV-1 infection and acquired immune deficiency virus syndrome: a review of the literature examining associations with HLA. Hum. Immunol., 44, 156-169.

Kaslow, R. A.; Carrington, M.; Apple, R.; Park, L.; Munoz, A.; Saah, A. J.; Goedert, J. J.; Winkler, C.; O’brien, S. J.; Mann, D. L. (1996), Influence of combinations of human major histocompatibility complex genes on the course of HIV-1 infection. Nature, 2, 405-411.

Klaassen, R. J. I.; Mulder, J. W.; Vlekke, A. B. J.; Eeftinck Schattenkerk, J. K. M.; Weigel, H. M.; Lange, J. M. A.; Von Dem Borne, A. E. G. K. (1990), Autoantibodies against peripheral blood cells appear early in HIV infection and their prevalence increases with disease progression. Clin. Exp. Immunol., 81, 11-17.

Mann, D. L.; Murray, C.; O’Donnel, M.; Blattner, W. A.; Goedett, J. J. (1990), HLA antigen frequencies in HIV-1-related Kaposi's sarcoma. J. Acquir. Immune Defic. Syndr., 3, 51-55.
Nepom, G. T. and Erlich, H. (1991), MHC class II molecules and autoimmunity. An. Rev. Immunol., 9, 493-525.

Pedersen, C.; Lindhardt, B. O.; Jensen, B. L.; Lauritzen, E.; Gerstoft, J.; Dickmeiss, E.; Gaub, J.; Scheibel, E.; Karlsmark, T. (1989), Clinical course of primary HIV infection: consequences for subsequent course of infection. $B M J, 299,154-157$.

Rhame, S. F. (1989), Acquired Immunodeficiency Syndrome. In: Hoeprich, P. D. and Jordan, M. C. (Eds.). Infection Diseases. Philadelphia: JB Lippincott Company.

Roitt, I.; Brostoff, J.; Male, D. (2001), Immunology. Edinburgh: Mosby.

Silvestris, F.; Williams, R. C.; Dammacco, F. (1995), Autoreactivity in HIV-1 infection: The role of molecular mimicry. Cl. Immunol Immunopathol, 75, 197-205.

Solheim, B. G.; Ryder, L. P.; Svejgaard, A. (1982), HLA and disease associations. In: Ferrone, S. and Solheim, B. G. (Eds.). HLA typing: methodology and clinical aspects. Pennsylvania: Franklin Book Co. Inc.

Tindall, B.; Carr, A.; Golfstein, D.; Penny, R.; Cooper, D. A. (1993), Administration of less vigorous immune response. AIDS, 7, 127-128.

Tiwari, J. L. and Terasaki, P. I. (1985), HLA and disease associations. New York: Springer-Verlag.

Walker, B. D. (1997), Imunologia relacionada à AIDS/SIDA. In: Bennett, J. C. and Plum, F. CECILTratado de Medicina Interna. Rio de Janeiro: Guanabara Koogan. 